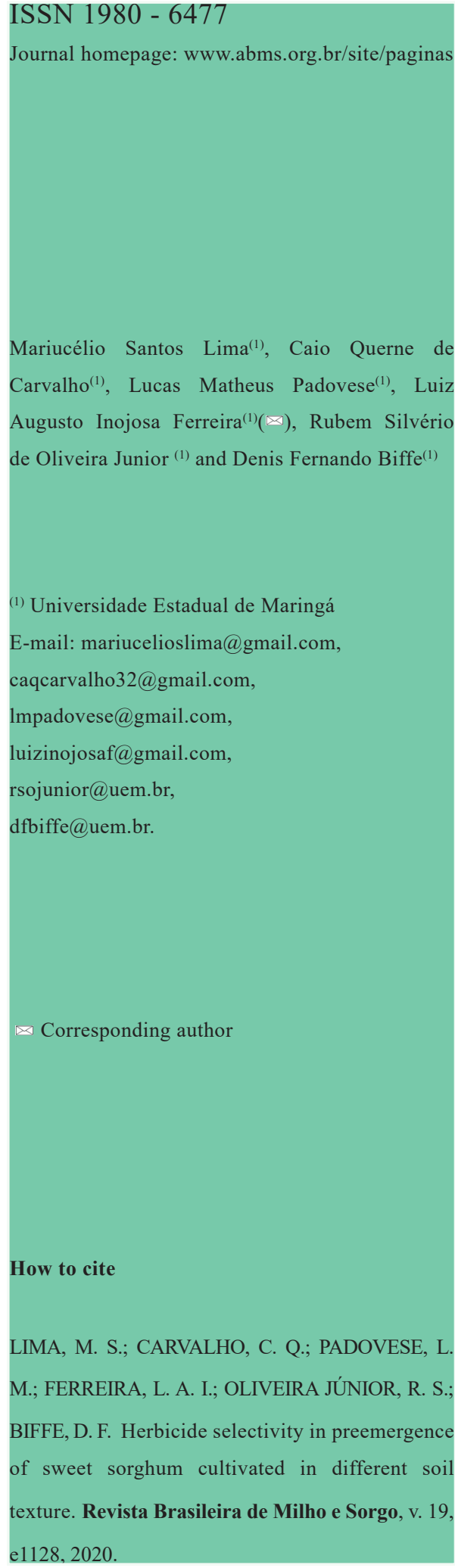

\section{HERBICIDE SELECTIVITY IN PREEMERGENCE OF SWEET SORGHUM CULTIVATED IN DIFFERENT SOIL TEXTURE}

\begin{abstract}
Sweet sorghum (Sorghum bicolor (L.) Moench) is an interesting alternative for biomass and ethanol production, however, so far there is very limited knowledge regarding selective herbicide options for weed control in this crop. The objective of this study was to evaluate the selectivity of preemergence herbicides for sweet sorghum. This research was composed by two steps: in the first one, a greenhouse screening was carried out with several herbicide treatments and in the following step the most selective treatments were evaluated on field conditions. In sandy clay loam texture soil, the treatments involving atrazine (1000 and $\left.2000 \mathrm{~g} \mathrm{ha}^{-1}\right)$, amicarbazone $\left(210 \mathrm{~g} \mathrm{ha}^{-1}\right)$, trifluralin $\left(500 \mathrm{~g} \mathrm{ha}^{-1}\right)$ and flumioxazin $\left(25 \mathrm{~g} \mathrm{ha}^{-1}\right)$ provided the greatest levels of selectivity to sweet sorghum. In clay soil (64.7\% clay), the treatments with atrazine (1000, 1500 and $\left.2000 \mathrm{~g} \mathrm{ha}^{-1}\right)$, amicarbazone (280 $\left.\mathrm{g} \mathrm{ha}^{-1}\right)$, S-metolachlor (480 $\left.\mathrm{g} \mathrm{ha}^{-1}\right)$, [atrazine $+\mathrm{S}$-metolachlor] $\left(\left[601+471,2 \mathrm{~g} \mathrm{ha}^{-1}\right)\right.$, pendimethalin $\left(500 \mathrm{~g} \mathrm{ha}^{-1}\right)$ and imazethapyr (42.4 and $63.6 \mathrm{~g} \mathrm{ha}^{-1}$ ) provided the lowest levels of crop injury, and were considered as the most selective for sweet sorghum. Herbicide treatments applied to sandy clay loam soil provided more injuries to sweet sorghum than those applied to clay soil.
\end{abstract}

Keywords: biomass, chemical control, ethanol, Sorghum bicolor.

\section{SELETIVIDADE DE HERBICIDAS APLICADOS EM PRÉ-EMERGÊNCIA DE SORGO SACARINO CULTIVADO EM SOLOS DE TEXTURA DIFERENTES}

\begin{abstract}
Resumo - O sorgo sacarino (Sorghum bicolor (L.) Moench) é uma alternativa interessante para produção de biomassa e de etanol, no entanto, ainda existem informações limitadas quanto às opções de herbicidas para controle de plantas daninhas na cultura. O objetivo deste trabalho foi avaliar a seletividade de herbicidas aplicados em pré-emergência da cultura do sorgo sacarino. Esta pesquisa foi constituída por duas etapas: na primeira, foi realizado um "screening" em casa de vegetação, e na segunda, os tratamentos mais seletivos foram avaliados em condições de campo. No solo de textura franco-argilo-arenosa ( $21 \%$ de argila), os tratamentos atrazine (1000 e $\left.2000 \mathrm{~g} \mathrm{ha}^{-1}\right)$, amicarbazone (210 $\left.\mathrm{g} \mathrm{ha}^{-1}\right)$, trifluralin $\left(500 \mathrm{~g} \mathrm{ha}^{-1}\right)$ e flumioxazin (25 g $\mathrm{ha}^{-1}$ ) apresentaram maior seletividade para o sorgo sacarino. No solo de textura argilosa (64,7\% de argila), tratamentos com atrazine (1000, 1500 e $\left.2000 \mathrm{~g} \mathrm{ha}^{-1}\right)$, amicarbazone (280 $\left.\mathrm{g} \mathrm{ha}^{-1}\right)$, S-metolachlor $\left(480 \mathrm{~g} \mathrm{ha}^{-1}\right)$, [atrazine + S-metolachlor] $([601+471,2]$ $\left.\mathrm{g} \mathrm{ha}^{-1}\right)$, pendimethalin $\left(500 \mathrm{~g} \mathrm{ha}^{-1}\right)$ e imazethapyr $\left(42,4\right.$ e $\left.63,6 \mathrm{~g} \mathrm{ha}^{-1}\right)$ apresentaram menores níveis de fitointoxicação, indicando os melhores níveis de seletividade para o sorgo sacarino. Os tratamentos aplicados em solo de textura franco-argilo-arenosa demonstraram maiores níveis de fitointoxicação em comparação àqueles aplicados em solo argiloso.
\end{abstract}

Palavras-chave: biomassa, controle químico, etanol, Sorghum bicolor. 
Sorghum originates from the African continent, more precisely from the region known as Ethiopia. Its domestication may have started in Egypt 3,000 years ago (Ribas, 2014). Sorghum is cultivated on more than 30 million hectares a year worldwide. Even so, it is considered in Brazil as a marginal crop, and, in most cases, is planted in inadequate soil and/or seasons and with little investment, even though it is very responsive to fertilization (Ribas, 2014). In Brazil, considering all types of sorghum, the expectation of the cultivation area for the $2019 / 2020$ season is about 732,2 thousand hectares (Conab, 2019).

Lately, strategies to reduce or even replace the fossil energy matrix by those from plant origin have been screened (Durães et al., 2012). Sugarcane is currently the main source that serves Brazil's bioenergetic matrix. However, research has been evolving in the search for other alternatives that could be added to sugarcane, meeting the demand for clean and renewable energy (Silva et al., 2014).

Sweet sorghum (Sorghum bicolor (L.) Moench) has been shown to be an excellent alternative for biomass and ethanol production, as it presents agronomic characteristics that are adapted to the needs of this industry sector, optimizing industrial production plants, since it can be used in the off-season of sugarcane and due to its fully mechanized implantation and harvesting (Albuquerque et al., 2012; Solano et al., 2017). Among the agronomic characteristics of interest, it is possible to highlight the short development cycle, tolerance to dry periods, high biomass production, high adaptation to the existing agricultural infrastructure and considerable levels of sugars in the stalks, which allows it to be cultivated throughout the country (Appiah-Nkansah et al., 2019; Maciel et al., 2017; Martins et al., 2017). In other words, compared to other crops in the production of bioenergy, such as sugarcane and sugarbeet, sweet sorghum needs less water, fertilizers and time for production (Appiah-Nkansah et al., 2019).

Although the crop is a very interesting alternative to optimize industrial plants that process sugarcane due to its agronomic characteristics, there is still a major bottleneck with regard to the management of weeds in the cultivation of sorghum. The number of products registered with the government competent bodies is limited (Correia \& Gomes, 2015). Among these products are atrazine, simazine and 2,4-D (MAPA, 2019). In addition, there is no information on the selectivity of herbicides specifically for sweet sorghum in soils of different textures.

Considering that the lack of chemical control alternatives hinders the management of weeds and, consequently, limits the expansion of cultivation in different regions of the country, the objective was to evaluate the selectivity of herbicides in the preemergence of sweet sorghum (Sorghum bicolor (L.) Moench).

\section{Material and methods}

\section{Greenhouse experiments:}


Initially, two experiments with soils of different textures (sandy clay loam and clayey) were installed in a greenhouse at the Irrigation Training Center of the State University of Maringá (CTI/UEM) (2323'44.70” S e 51'57'3.23” O, at 510 meters above sea level), in Maringá state of Paraná. The conduction period for the experiments was from April to June 2016. The hybrid used was the N31G2091, which belongs to the sweet sorghum material line.

The soils used in the experiments had the following physical-chemical characteristics: soil with clay-sandy texture: coarse sand $=59.3 \%$, fine sand $=12.6 \%$, clay $=21 \%$ and silt $=7.1 \%$, $\mathrm{pH}\left(\mathrm{H}_{2} \mathrm{O}\right)=6.2$ and $\mathrm{CTC}=5.05 \mathrm{cmolc}_{\mathrm{c}} \cdot \mathrm{dm}^{-3}$; clayey texture soil: coarse sand $=3.5 \%$, fine sand $=6.8 \%$, clay $=64.7 \%$ and silt $=25 \%$, with $\mathrm{pH}$ $\left(\mathrm{H}_{2} \mathrm{O}\right)=6.0$ and $\mathrm{CTC}=10.02 \mathrm{cmolc}_{\mathrm{c} .} \mathrm{dm}^{-3}$.

In both experiments, 37 preemergence treatments were applied, with four replications, installed in a completely randomized design. The treatments $\left(\mathrm{g} \mathrm{ha}^{-1}\right)$ were: atrazine $(2000,1500$ and 1000), amicarbazone (280, 210 and 140), S-metolachlor (960, 720 and 480), trifluralin (1000, 750 and 500), pendimethalin (1000, 750 and 500), [atrazine + S-metolachlor] ([1202 $+942.5],[901.5+706.8]$ and [601 + 471.2]), clomazone (500, 375 and 250), clomazone (500, 375 and 250) with seeds treated with the Dietholate safener (Permit Star, $625 \mathrm{~mL}$ p.c. $100 \mathrm{~kg}^{-1}$ seeds), isoxaflutole (60, 45 and 30), pyroxsulam (18; 13.5 and 9), imazethapyr (84.8; 63.6 and 42.4), flumioxazin (50, 37.5 and 25) and control without herbicide.

The experimental units were composed of pots with a capacity of $3.5 \mathrm{dm}^{3}$ of soil and six sorghum seeds, sown at $2 \mathrm{~cm}$ depth. After sowing, the soil was irrigated and herbicides were applied on the same day.

For herbicide applications, a $\mathrm{CO}_{2}$ pressurized backpack sprayer was used, equipped with a three-nozzle spray boom XR 110.02 (40 lbf $i^{-2}$ ), spaced $50 \mathrm{~cm}$ apart, at a height of $50 \mathrm{~cm}$ in relation to the target, delivering a volume of 200 $\mathrm{L} \mathrm{ha}^{-1}$. During the application of the treatments, the temperature was $28^{\circ} \mathrm{C}$, relative humidity of $60 \%$ and average wind speed of $3 \mathrm{~km} \mathrm{~h}^{-1}$.

For both experiments conducted in a greenhouse, the phytointoxication of sorghum plants (visual evaluation from 0 to $100 \%, 0$ with no symptoms of phytointoxication and $100 \%$ death of the crop) was evaluated at 28 days after emergence (DAE). Chlorophyll content evaluations (SPAD index - average of five readings per pot, obtained at the tips of the last expanded leaves, at 28 DAE), culm height (mean of the sorghum plants in the pot, from soil level to insertion) were also performed of the last expanded leaf, at $28 \mathrm{DAE}$ ), and dry matter mass of the aerial part, also at $28 \mathrm{DAE}$ (after collecting the aerial part and drying in a forced ventilation oven, with a temperature of $58^{\circ} \mathrm{C}$, until the sample weight stabilization).

\section{Field experiments:}

Based on the experiments carried out in the greenhouse, the treatments considered most 
selective were selected for further evaluation in the field. The experimental design used was a randomized block consisting of six replicates for the two field experiments. The experimental units were composed of plots of seven lines of sorghum with a spacing of $0.45 \mathrm{~m}$ and $5 \mathrm{~m}$ in length (total area of $15.75 \mathrm{~m}^{2}$ ). The entire area of the experiments was dessicated with glyphosate (1080 $\mathrm{g} \mathrm{ha}^{-1}$ ) 15 days before the sowing date, which was carried out in no-tillage system.

The climatic data related to the period of conduction of the experiments were collected at the agrometeorological station of the National Institute of Meteorology (INMET) - Campus Sede UEM - Maringá - PR, and are shown in Figure 1.

All treatments were weeded according to need, throughout the crop cycle as a local control.

The first field experiment was installed in Maringá (PR), Iguatemi district, at the Iguatemi
Experimental Farm (FEI/UEM) (2321'2.17' S; $52^{\circ} 04 ' 16.52 " \mathrm{O}$ at 555 meters above sea level). The period of conduction of the experiments was from February to June 2017. The hybrid used for sowing was the N31G2091. The local soil, which had previously been cultivated with corn for silage, was classified as dystrophic RED LATOSOL (Embrapa, 2013), with a clay-sandy texture $($ coarse sand $=50.8 \%$, fine sand $=23.7 \%$, clay $=20.4 \%$ and silt $=5.1 \%, \mathrm{pH}\left(\mathrm{H}_{2} \mathrm{O}\right)=6.0$ and $\left.\mathrm{CTC}=4.82 \mathrm{cmolc}_{\mathrm{c}} \cdot \mathrm{dm}^{-3}\right)$.

From the results of the greenhouse screening with the loam-clay-sandy soil, 13 treatments were selected for the field experimente $\left(\mathrm{g} \mathrm{ha}^{-1}\right)$ : atrazine (2000, 1500 and 1000), amicarbazone (210 and 140), S-metolachlor (480), trifuralin (500), pendimethalin (1000, 750 and 500), [atrazine + S-metolachlor] $([601+471,2])$, flumioxazin (25) and control without herbicide.

Sowing was carried out on 03/08/2017,

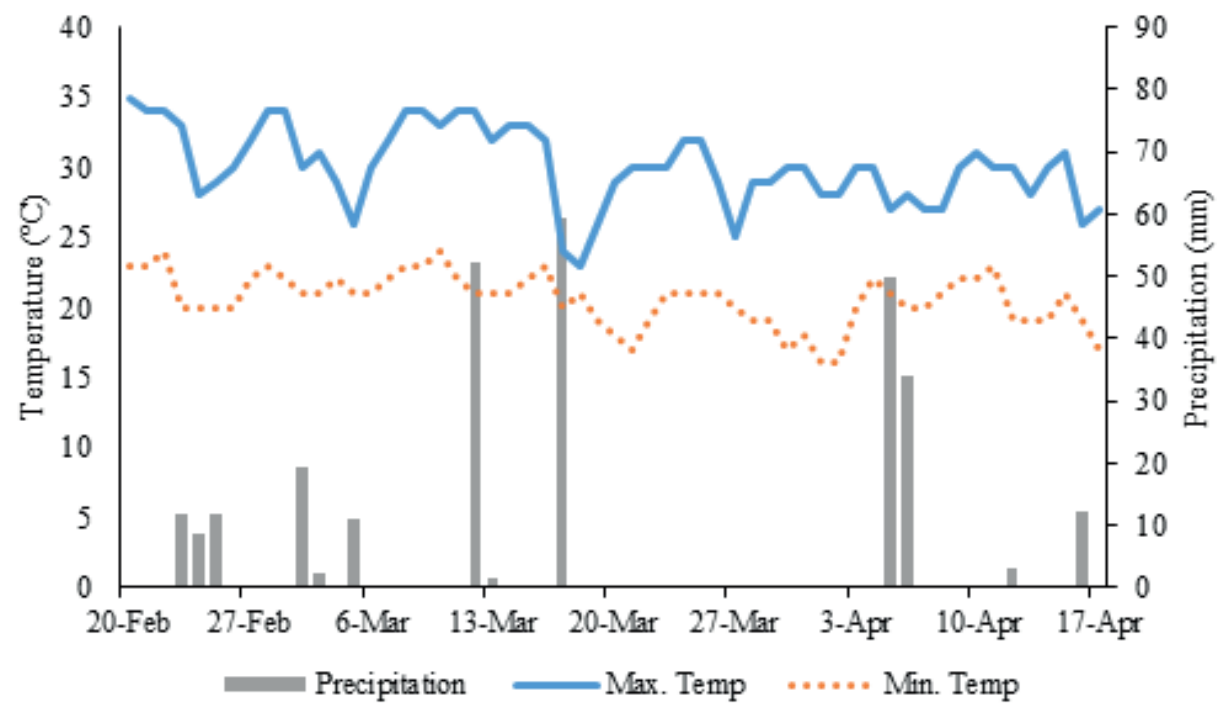

Figure 1. Climatic data observed during the period of conducting the selectivity experiments. 
adopting a density of 8 seeds $\mathrm{m}^{-1}$, and emergence was considered when more than $70 \%$ of the plants were emerged. Fertilization at sowing was carried out using $300 \mathrm{~kg} \mathrm{ha}^{-1}$ of the formulation 08-20$20(0.3 \% \mathrm{Zn})$, and na additional fertilization was carried out on $04 / 08 / 2017$ using $98 \mathrm{~kg} \mathrm{ha}^{-1}$ of protected urea.

The treatments were applied with a $\mathrm{CO}_{2}$ pressurized backpack sprayer, equipped with three-nozzle spray boom ST-IA 135.015 ( $35 \mathrm{lb}$ $\mathrm{in}^{-2}$ ), spaced $50 \mathrm{~cm}$ apart, delivering a spray volume equivalent to $150 \mathrm{~L} \mathrm{ha}^{-1}$. At the time of application, the temperature was $21^{\circ} \mathrm{C}, 65 \%$ relative humidity, and an average wind speed of $4 \mathrm{~km} \mathrm{~h}^{-1}$.

The second field experiment was conducted in Mandaguaçu (PR), in Pulinópolis district $\left(23^{\circ} 14^{\prime} 24.65^{\prime \prime} \mathrm{S}, 52^{\circ} 0^{\prime} 21.10^{\prime \prime} \mathrm{O}\right.$ at 462 meters above sea level). The local soil, classified as dystrophic RED LATOSOL (Embrapa, 2013), has a clayey texture (coarse sand $=17.1 \%$; fine sand $=$ $7.5 \%$, clay $=60.8 \%, \mathrm{pH}\left(\mathrm{H}_{2} \mathrm{O}\right)=5.6$ and $\mathrm{CTC} 8.33$ $\left.\mathrm{cmolc}_{\mathrm{c}} \cdot \mathrm{dm}^{-3}\right)$.

Seventeen treatments were selected based on the results of the clayey soil in the greenhouse, including ( $\left.\mathrm{g} \mathrm{ha}^{-1}\right)$ : atrazine (2000, 1500 and 1000), amicarbazone (280, 210 and 140), S-metolachlor (480), trifuralin (500), pendimethalin (1000, 750 and 500), [atrazine + S-metolachlor] ([601 $+471.2]$ ), imazethapyr (84.8; 63.6 and 42.4), flumioxazin (25) and control without herbicide.

The treatments were applied under a temperature of $23^{\circ} \mathrm{C}$, relative humidity of $60 \%$ and an average wind speed of $2 \mathrm{~km} \mathrm{~h}^{-1}$, with the same equipment used for the first field-level experiment.
For both experiments, evaluations of stand (plants $5 \mathrm{~m}^{-1}$ ) and phytointoxication of sorghum plants (visual scores from 0 to $100 \%$, 0 with no symptoms of phytointoxication and $100 \%$ as crop death) were performed at 28 days after emergence. In addition, the height, green matter mass of the aerial part, percentage of dry matter and Brix of the plants were also evaluated at 28 DAE.

Brix was measured at the tips of the fourth node of the plant, counting from the base of the inflorescence downwards, in three plants of the central lines of the plots. The harvest of the two field experiments was carried out at 70 DAE, after the beginning of the flowering of the culture, when Brix of the sap in sampling carried out in the control plots showed a minimum concentration of $7^{\circ} \mathrm{Bx}$.

The data obtained were submitted to analysis of variance by the $\mathrm{F}$ test and the means with significant effect, compared by the ScottKnott test, at $5 \%$ probability of error.

\section{Results and discussion}

\section{Greenhouse - Sandy clay loam soil:}

Treatments with trifluralin $(1000 \mathrm{~g}$ ha $\left.^{-1}\right)$, [atrazine + S-metolachlor] $([1202+$ 942.5] and [901.5 + 706.8] $\mathrm{g} \mathrm{ha}^{-1}$ ), clomazone, clomazone + safener, isoxaflutole, pyroxsulam and imazethapyr in all doses and flumioxazin (at 50 and $37.5 \mathrm{~g} \mathrm{ha}^{-1}$ ) provided high levels of phytointoxication. In the treatments with 
clomazone, there was no significant difference between doses, even when the sorghum seeds were treated with Permit Star (safener), and all of them presented strong chlorosis (Table 1). In an experiment carried out by Silva et al. (2017) in order to assess the sensitivity of forage and weed plants to atmospheric residual concentrations of clomazone, the authors observed a gradual increase in intoxication of sorghum plants according to the evaluation periods, with higher values in the concentration of $0.20 \mathrm{mg} \mathrm{L}^{-1}$ (equivalent to a dose of $360 \mathrm{~g} \mathrm{ha}^{-1}$ ), corroborating the results found in this study.

Treatments with amicarbazone $(210 \mathrm{~g}$ ha $^{-1}$ ), S-metolachlor (960, 720 and $480 \mathrm{~g} \mathrm{ha}^{-1}$ ), trifluralin (750 and $\left.500 \mathrm{~g} \mathrm{ha}^{-1}\right)$, pendimethalin (1000, 750 and $\left.500 \mathrm{~g} \mathrm{ha}^{-1}\right)$, [atrazine + S-metolachlor $]\left([601+471.2] \mathrm{g} \mathrm{ha}^{-1}\right)$ and flumioxazin $\left(25 \mathrm{~g} \mathrm{ha}^{-1}\right)$ presented considerable levels of phytointoxication, with values $\geq 42.5 \%$.

There were no changes in height and chlorophyll content (SPAD index) compared to the control without herbicide in the treatments with atrazine (2000, 1500 and $\left.1000 \mathrm{~g} \mathrm{ha}^{-1}\right)$, amicarbazone $\left(280,210\right.$ and $\left.140 \mathrm{~g} \mathrm{ha}^{-1}\right)$, Smetolachlor (720 $\left.\mathrm{g} \mathrm{ha}^{-1}\right)$, trifluralin (750 and $\left.500 \mathrm{~g} \mathrm{ha}^{-1}\right)$, pendimethalin $(1000,750$ and $500 \mathrm{~g}$ $\mathrm{ha}^{-1}$ ), imazethapyr (42.4 $\left.\mathrm{g} \mathrm{ha}^{-1}\right)$ and flumioxazin $\left(25 \mathrm{~g} \mathrm{ha}^{-1}\right)$. Pendimethalin $\left(500 \mathrm{~g} \mathrm{ha}^{-1}\right)$ was the only treatment that did not present a significant difference in the aerial part dry matter mass (MMSPA) in relation to the control without herbicide.

Considering the results of the phytointoxication evaluations, the treatments with atrazine (2000 and $1000 \mathrm{~g} \mathrm{ha}^{-1}$ ) and amicarbazone (280 and $140 \mathrm{~g} \mathrm{ha}^{-1}$ ) did not present any significant difference in relation to the control without herbicide. In general, the vast majority of herbicide treatments showed phytointoxication levels $\geq 50 \%$.

Regarding treatments containing FS II inhibitors (atrazine and amicarbazone) and cell division (S-metolachlor, trifluralin and pendimethalin), the effects on plant phytoxication and development, in general, are minor and variable depending on the doses used, indicating that such treatments may present a greater possibility of use in this soil texture.

\section{Greenhouse - Clay texture soil:}

The treatments with atrazine $\left(1000 \mathrm{~g} \mathrm{ha}^{-1}\right)$, trifuralin (500 $\left.\mathrm{g} \mathrm{ha}^{-1}\right)$ and imazethapyr (63.6 and $\left.42.4 \mathrm{~g} \mathrm{ha}^{-1}\right)$, in general, did not differ significantly from the control without herbicides (Table 2).

For treatments with S-metolachlor (960 and $\left.720 \mathrm{~g} \mathrm{ha}^{-1}\right)$, trifuralin (1000 $\left.\mathrm{g} \mathrm{ha}^{-1}\right)$, [atrazine + S-metolachlor $]([1202+942.5]$ and $[901.5+$ 706.8 ] $\left.\mathrm{g} \mathrm{ha}^{-1}\right)$, clomazone + safener $(500,375$ and $\left.250 \mathrm{~g} \mathrm{ha}^{-1}\right)$, clomazone (500, 375 and $\left.250 \mathrm{~g} \mathrm{ha}^{-1}\right)$, isoxaflutole $\left(60,45\right.$ and $\left.30 \mathrm{~g} \mathrm{ha}^{-1}\right)$, pyroxsulam $\left(18,13.5\right.$ and $\left.9 \mathrm{~g} \mathrm{ha}^{-1}\right)$ and flumioxazin (50 and $37.5 \mathrm{~g} \mathrm{ha}^{-1}$ ) significant differences were observed in relation to the control without herbicide with very high levels of phytointoxication ( $\geq 65 \%$ ). As in the sandy clay loam soil, treatments involving clomazone, with or without Permit (safener), did not show significant difference between doses, 
Table 1. Phytintoxication percentages (visual assessment 0 to $100 \%$ ), height, dry matter weight of the aerial part (DMAP) and chlorophyll content (SPAD) of sweet sorghum (28 DAE) after application of the herbicides in preemergence in sandy clay loam soil (greenhouse).

\begin{tabular}{lcccc}
\hline \multicolumn{1}{c}{ Treatments $\left(\mathrm{g} \mathrm{ha}^{-1}\right)$} & $\begin{array}{c}\text { Phytointoxication } \\
(\%)\end{array}$ & $\begin{array}{c}\text { Height } \\
(\mathrm{cm})\end{array}$ & $\begin{array}{c}\text { DMAP } \\
\left(\mathrm{g} \mathrm{pot}^{-1}\right)\end{array}$ & SPAD \\
\hline atrazine (2000) & $2.50 \mathrm{c}$ & $11.25 \mathrm{a}$ & $0.83 \mathrm{~b}$ & $34.25 \mathrm{a}$ \\
atrazine (1500) & $28.75 \mathrm{~b}$ & $7.50 \mathrm{a}$ & $0.53 \mathrm{~b}$ & $24.30 \mathrm{a}$ \\
atrazine (1000) & $6.25 \mathrm{c}$ & $9.00 \mathrm{a}$ & $0.68 \mathrm{~b}$ & $29.05 \mathrm{a}$ \\
amicarbazone (280) & $26.25 \mathrm{c}$ & $7.50 \mathrm{a}$ & $0.34 \mathrm{c}$ & $29.90 \mathrm{a}$ \\
amicarbazone (210) & $42.50 \mathrm{~b}$ & $5.75 \mathrm{a}$ & $0.31 \mathrm{c}$ & $31.30 \mathrm{a}$ \\
amicarbazone (140) & $16.25 \mathrm{c}$ & $8.25 \mathrm{a}$ & $0.73 \mathrm{~b}$ & $20.68 \mathrm{a}$ \\
S-metolachlor (960) & $61.25 \mathrm{~b}$ & $3.50 \mathrm{~b}$ & $0.25 \mathrm{c}$ & $22.75 \mathrm{a}$ \\
S-metolachlor (720) & $58.75 \mathrm{~b}$ & $6.00 \mathrm{a}$ & $0.33 \mathrm{c}$ & $26.33 \mathrm{a}$ \\
S-metolachlor (480) & $66.25 \mathrm{~b}$ & $6.50 \mathrm{a}$ & $0.18 \mathrm{c}$ & $9.03 \mathrm{~b}$ \\
trifluralin (1000) & $85.00 \mathrm{a}$ & $2.00 \mathrm{~b}$ & $0.10 \mathrm{c}$ & $33.35 \mathrm{a}$ \\
trifluralin (750) & $55.00 \mathrm{~b}$ & $8.25 \mathrm{a}$ & $0.62 \mathrm{~b}$ & $34.38 \mathrm{a}$ \\
trifluralin (500) & $50.00 \mathrm{~b}$ & $6.75 \mathrm{a}$ & $0.46 \mathrm{~b}$ & $26.53 \mathrm{a}$ \\
pendimethalin (1000) & $60.00 \mathrm{~b}$ & $7.50 \mathrm{a}$ & $0.71 \mathrm{~b}$ & $25.58 \mathrm{a}$ \\
pendimethalin (750) & $67.00 \mathrm{~b}$ & $5.00 \mathrm{a}$ & $0.62 \mathrm{~b}$ & $25.48 \mathrm{a}$ \\
pendimethalin (500) & $55.00 \mathrm{~b}$ & $8.25 \mathrm{a}$ & $1.42 \mathrm{a}$ & $19.18 \mathrm{a}$ \\
[atrazine+S-metolachlor] [1202+942.5] & $91.00 \mathrm{a}$ & $3.50 \mathrm{~b}$ & $0.11 \mathrm{c}$ & $19.28 \mathrm{a}$ \\
[atrazine+S-metolachlor] [901.5+706.8] & $87.00 \mathrm{a}$ & $3.50 \mathrm{~b}$ & $0.18 \mathrm{c}$ & $27.15 \mathrm{a}$ \\
[atrazine+S-metolachlor] [601+471.2] & $56.25 \mathrm{~b}$ & $5.50 \mathrm{~b}$ & $0.28 \mathrm{c}$ & $0.00 \mathrm{~b}$ \\
clomazone+safener (500) & $99.50 \mathrm{a}$ & $0.25 \mathrm{~b}$ & $0.00 \mathrm{c}$ & $0.00 \mathrm{~b}$ \\
clomazone+safener (375) & $100.00 \mathrm{a}$ & $0.00 \mathrm{~b}$ & $0.00 \mathrm{c}$ & $0.00 \mathrm{~b}$ \\
clomazone+safener (250) & $97.50 \mathrm{a}$ & $1.00 \mathrm{~b}$ & $0.00 \mathrm{c}$ & $0.00 \mathrm{~b}$ \\
clomazone (500) & $100.00 \mathrm{a}$ & $0.00 \mathrm{~b}$ & $0.00 \mathrm{c}$ & $0.00 \mathrm{~b}$ \\
clomazone (375) & $99.50 \mathrm{a}$ & $0.25 \mathrm{~b}$ & $0.01 \mathrm{c}$ & $0.00 \mathrm{~b}$ \\
clomazone (250) & $99.50 \mathrm{a}$ & $0.25 \mathrm{~b}$ & $0.01 \mathrm{c}$ & $0.00 \mathrm{~b}$ \\
isoxaflutole (60) & $99.75 \mathrm{a}$ & $0.25 \mathrm{~b}$ & $0.01 \mathrm{c}$ & $0.00 \mathrm{~b}$ \\
isoxaflutole (45) & $99.50 \mathrm{a}$ & $0.25 \mathrm{~b}$ & $0.01 \mathrm{c}$ & $0.00 \mathrm{~b}$ \\
isoxaflutole (30) & $99.50 \mathrm{a}$ & $0.25 \mathrm{~b}$ & $0.01 \mathrm{c}$ & $0.00 \mathrm{~b}$ \\
pyroxsulam (18) & $98.00 \mathrm{a}$ & $0.00 \mathrm{~b}$ & $0.01 \mathrm{c}$ & $0.00 \mathrm{~b}$ \\
pyroxsulam (13.5) & $95.50 \mathrm{a}$ & $0.50 \mathrm{~b}$ & $0.02 \mathrm{c}$ & $0.00 \mathrm{~b}$ \\
pyroxsulam (9) & $74.50 \mathrm{a}$ & $1.50 \mathrm{~b}$ & $0.07 \mathrm{c}$ & $0.00 \mathrm{~b}$ \\
imazethapyr(84.8) & $95.00 \mathrm{a}$ & $2.50 \mathrm{~b}$ & $0.10 \mathrm{c}$ & $7.23 \mathrm{~b}$
\end{tabular}


Table 1 (continuation). Phytintoxication percentages (visual assessment 0 to 100\%), height, dry matter weight of the aerial part (DMAP) and chlorophyll content (SPAD) of sweet sorghum (28 DAE) after application of the herbicides in preemergence in sandy clay loam soil (greenhouse).

\begin{tabular}{lcccc} 
imazethapyr (63.6) & $96.50 \mathrm{a}$ & $1.50 \mathrm{~b}$ & $0.07 \mathrm{c}$ & $2.85 \mathrm{~b}$ \\
imazethapyr (42.4) & $82.00 \mathrm{a}$ & $5.75 \mathrm{a}$ & $0.29 \mathrm{c}$ & $27.95 \mathrm{a}$ \\
flumioxazin (50) & $99.50 \mathrm{a}$ & $0.50 \mathrm{~b}$ & $0.01 \mathrm{c}$ & $0.00 \mathrm{~b}$ \\
flumioxazin (37.5) & $95.00 \mathrm{a}$ & $1.50 \mathrm{~b}$ & $0.05 \mathrm{c}$ & $8.38 \mathrm{~b}$ \\
flumioxazin (25) & $58.75 \mathrm{~b}$ & $6.25 \mathrm{a}$ & $0.38 \mathrm{c}$ & $23.45 \mathrm{a}$ \\
Control & $0.00 \mathrm{c}$ & $12.25 \mathrm{a}$ & $1.30 \mathrm{a}$ & $32.00 \mathrm{a}$ \\
\hline F & $9.61^{* *}$ & $5.85 * *$ & $4.14^{* *}$ & $7.90^{* *}$ \\
$\mathrm{CV}(\%)$ & 28.75 & 72.77 & 114.06 & 62.41 \\
\hline
\end{tabular}

** Means in the same column followed by the same letter do not differ, at $5 \%$ probability by the Scott-Knott test.

Table 2. Phytointoxication percentages (visual assessment 0 to $100 \%$ ), height, dry matter weight of the aerial part (DMAP) and chlorophyll content (SPAD) of sweet sorghum (28 DAE) after the application of the herbicides in preemergence in clayey soil (greenhouse).

\begin{tabular}{lcccc}
\hline \multicolumn{1}{c}{ Treatments $\left(\mathrm{g} \mathrm{ha}^{-1}\right)$} & $\begin{array}{c}\text { Phytointoxication } \\
(\%)\end{array}$ & $\begin{array}{c}\text { Height } \\
(\mathrm{cm})\end{array}$ & $\begin{array}{c}\text { DMAP }\left(\mathrm{g} \mathrm{pot}^{-1}\right) \\
\text { SPAD }\end{array}$ \\
\hline atrazine (2000) & $20.00 \mathrm{~d}$ & $9.25 \mathrm{~b}$ & $0.54 \mathrm{~d}$ & $32.40 \mathrm{a}$ \\
atrazine (1500) & $45.00 \mathrm{c}$ & $6.75 \mathrm{~b}$ & $0.58 \mathrm{~d}$ & $21.35 \mathrm{a}$ \\
atrazine (1000) & $0.00 \mathrm{e}$ & $11.50 \mathrm{a}$ & $1.58 \mathrm{c}$ & $30.80 \mathrm{a}$ \\
amicarbazone (280) & $52.50 \mathrm{c}$ & $8.00 \mathrm{~b}$ & $0.60 \mathrm{~d}$ & $30.48 \mathrm{a}$ \\
amicarbazone (210) & $17.50 \mathrm{~d}$ & $11.00 \mathrm{a}$ & $1.18 \mathrm{c}$ & $31.15 \mathrm{a}$ \\
amicarbazone (140) & $30.00 \mathrm{c}$ & $10.00 \mathrm{~b}$ & $1.10 \mathrm{c}$ & $26.98 \mathrm{a}$ \\
S-metolachlor (960) & $67.50 \mathrm{~b}$ & $8.75 \mathrm{~b}$ & $0.28 \mathrm{~d}$ & $29.93 \mathrm{a}$ \\
S-metolachlor (720) & $92.50 \mathrm{a}$ & $2.00 \mathrm{~d}$ & $0.13 \mathrm{~d}$ & $5.93 \mathrm{c}$ \\
S-metolachlor (480) & $25.00 \mathrm{~d}$ & $9.00 \mathrm{~b}$ & $0.85 \mathrm{~d}$ & $28.98 \mathrm{a}$ \\
trifluralin (1000) & $65.00 \mathrm{~b}$ & $7.75 \mathrm{~b}$ & $0.40 \mathrm{~d}$ & $27.50 \mathrm{a}$ \\
trifluralin (750) & $51.25 \mathrm{c}$ & $7.50 \mathrm{~b}$ & $0.63 \mathrm{~d}$ & $33.93 \mathrm{a}$ \\
trifluralin (500) & $10.00 \mathrm{e}$ & $12.25 \mathrm{a}$ & $1.40 \mathrm{c}$ & $30.90 \mathrm{a}$ \\
pendimethalin (1000) & $35.00 \mathrm{c}$ & $12.25 \mathrm{a}$ & $2.16 \mathrm{~b}$ & $32.30 \mathrm{a}$ \\
pendimethalin (750) & $17.50 \mathrm{~d}$ & $13.25 \mathrm{a}$ & $2.07 \mathrm{~b}$ & $31.95 \mathrm{a}$ \\
pendimethalin (500) & $25.00 \mathrm{~d}$ & $10.50 \mathrm{a}$ & $1.27 \mathrm{c}$ & $32.28 \mathrm{a}$ \\
[atrazine+S-metolachlor] [1202+942.5] & $75.00 \mathrm{~b}$ & $5.50 \mathrm{c}$ & $0.16 \mathrm{~d}$ & $14.25 \mathrm{~b}$ \\
[atrazine+S-metolachlor] [901.5+706.8] & $70.00 \mathrm{~b}$ & $8.25 \mathrm{~b}$ & $0.16 \mathrm{~d}$ & $32.13 \mathrm{a}$
\end{tabular}


Table 2(continuation). Phytointoxication percentages (visual assessment 0 to $100 \%$ ), height, dry matter weight of the aerial part (DMAP) and chlorophyll content (SPAD) of sweet sorghum (28 DAE) after the application of the herbicides in preemergence in clayey soil (greenhouse).

\begin{tabular}{lcccc} 
[atrazine+S-metolachlor] [601+471.2] & $22.50 \mathrm{~d}$ & $12.50 \mathrm{a}$ & $0.83 \mathrm{~d}$ & $34.23 \mathrm{a}$ \\
clomazone+safener (500) & $100.00 \mathrm{a}$ & $0.00 \mathrm{~d}$ & $0.00 \mathrm{~d}$ & $0.00 \mathrm{c}$ \\
clomazone+safener (375) & $99.75 \mathrm{a}$ & $0.00 \mathrm{~d}$ & $0.00 \mathrm{~d}$ & $0.00 \mathrm{c}$ \\
clomazone+safener (250) & $99.25 \mathrm{a}$ & $0.00 \mathrm{~d}$ & $0.00 \mathrm{~d}$ & $0.00 \mathrm{c}$ \\
clomazone (500) & $100.00 \mathrm{a}$ & $0.00 \mathrm{~d}$ & $0.00 \mathrm{~d}$ & $0.00 \mathrm{c}$ \\
clomazone (375) & $97.50 \mathrm{a}$ & $1.75 \mathrm{~d}$ & $0.04 \mathrm{~d}$ & $3.75 \mathrm{c}$ \\
clomazone (250) & $93.75 \mathrm{a}$ & $4.25 \mathrm{c}$ & $0.12 \mathrm{~d}$ & $15.95 \mathrm{~b}$ \\
isoxaflutole (60) & $94.50 \mathrm{a}$ & $1.25 \mathrm{~d}$ & $0.02 \mathrm{~d}$ & $0.00 \mathrm{c}$ \\
isoxaflutole (45) & $89.25 \mathrm{a}$ & $3.25 \mathrm{c}$ & $0.13 \mathrm{~d}$ & $29.43 \mathrm{a}$ \\
isoxaflutole (30) & $77.50 \mathrm{~b}$ & $5.00 \mathrm{c}$ & $0.30 \mathrm{~d}$ & $28.30 \mathrm{a}$ \\
pyroxsulam (18) & $96.50 \mathrm{a}$ & $1.00 \mathrm{~d}$ & $0.01 \mathrm{~d}$ & $0.00 \mathrm{c}$ \\
pyroxsulam (13.5) & $80.00 \mathrm{~b}$ & $7.75 \mathrm{~b}$ & $0.39 \mathrm{~d}$ & $33.50 \mathrm{a}$ \\
pyroxsulam (9) & $85.50 \mathrm{a}$ & $4.50 \mathrm{c}$ & $0.38 \mathrm{~d}$ & $32.58 \mathrm{a}$ \\
imazethapyr (84.8) & $22.50 \mathrm{~d}$ & $10.00 \mathrm{~b}$ & $1.33 \mathrm{c}$ & $25.85 \mathrm{a}$ \\
imazethapyr (63.6) & $0.00 \mathrm{e}$ & $12.50 \mathrm{a}$ & $3.11 \mathrm{a}$ & $28.25 \mathrm{a}$ \\
imazethapyr (42.4) & $0.00 \mathrm{e}$ & $14.00 \mathrm{a}$ & $1.83 \mathrm{c}$ & $30.73 \mathrm{a}$ \\
flumioxazin (50) & $81.25 \mathrm{~b}$ & $6.75 \mathrm{~b}$ & $0.28 \mathrm{~d}$ & $34.55 \mathrm{a}$ \\
flumioxazin (37.5) & $77.50 \mathrm{~b}$ & $8.25 \mathrm{~b}$ & $0.31 \mathrm{~d}$ & $34.10 \mathrm{a}$ \\
flumioxazin (25) & $18.75 \mathrm{~d}$ & $10.00 \mathrm{~b}$ & $1.15 \mathrm{c}$ & $30.88 \mathrm{a}$ \\
Control & $0.00 \mathrm{e}$ & $8.75 \mathrm{~b}$ & $0.46 \mathrm{~d}$ & $33.13 \mathrm{a}$ \\
\hline F & $23.28^{* *}$ & $6.54^{* *}$ & $7.61 * *$ & $16.9 * *$ \\
CV (\%) & 26.90 & 46.42 & 77.10 & 26.51 \\
\hline
\end{tabular}

** Means in the same column followed by the same letter do not differ, at $5 \%$ probability by the Scott-Knott test.

with strong chlorosis evolving to plant death. According to Karam et al. (2002), the reduction in the symptoms of intoxication generated by the presence of the safener occurs with the increase in the detoxification of the herbicide due to the increase in enzymatic activity.

Machado et al. (2016) found that in the applications of trifluralin (1200 $\left.\left.\mathrm{g} \mathrm{ha}^{-1}\right), \mathrm{ha}^{-1}\right)$, amicarbazone $\left(210 \mathrm{~g} \mathrm{ha}^{-1}\right)$, trifluralin $(500$
S-metolachlor $\left(768 \mathrm{~g} \mathrm{ha}^{-1}\right)$ and clomazone $(1000$ $\mathrm{g} \mathrm{ha}^{-1}$ ) in preemergence of sorghum, in clay soil, maximum levels of $53.3 \%$ of phytointoxication were found, however, the evaluations were carried out only until $21 \mathrm{DAE}$, that is, one week less when compared to our study.

Treatments containing atrazine $(1000 \mathrm{~g}$ 
$\left.\mathrm{g} \mathrm{ha}^{-1}\right)$, pendimethalin $\left(1000,750\right.$ and $\left.500 \mathrm{~g} \mathrm{ha}^{-1}\right)$, [atrazine $+\mathrm{S}$-metolachlor] $\left([601+471.2] \mathrm{g} \mathrm{ha}^{-1}\right)$, and imazethapyr (63.6 and $42.4 \mathrm{~g} \mathrm{ha}^{-1}$ ) presented the best results for height and SPAD index among all herbicidal treatments. Isoxaflutole (30 and 45 $\mathrm{g} \mathrm{ha}^{-1}$ ), even without affecting the SPAD index, showed a high level of phytointoxication, which consequently affected the height of the sorghum plants.

Regarding treatments containing FS II inhibitors (atrazine and amicarbazone), cell division (trifluralin and pendimethalin), ALS inhibitors (imazethapyr) and PROTOX inhibitors (flumyzin), the effects on plant phytoxication and development are generally minor and depending on the doses used, indicating that such treatments may present greater possibility of use in this type of soil.

\section{Field:}

The treatments considered most selective in greenhouse tests were studied in the field, aiming to evaluate the effect of herbicides on important characteristics related to the production of biomass for energy generation, such as the weight of green matter in the aerial part, percentage of dry matter in the aerial part and Brix of sweet sorghum plants.

\section{Sandy clay loam soil:}

In atrazine treatments, low levels of phytointoxication are observed, with few injuries caused by the herbicide, presenting only a slight yellowing at 28 DAE. Similar behavior was observed in the treatment with flumioxazin, in which, despite a low level of phytointoxication, there was a significant difference from the control without herbicide (Table 3). For flumioxazin applied at $50 \mathrm{~g} \mathrm{ha}^{-1}$ in the cultivar BRS 509 of sweet sorghum, minor phytointoxication (5.5\%) was also observed in the study conducted by Galon et al. (2016) in clay soil.

For all treatments with amicarbazone, S-metolachlor, trifluralin, pendimethalin and [atrazine + S-metolachlor], significant phytointoxication was observed in relation to the control without herbicide. The herbicides amicarbazone (280 and $\left.210 \mathrm{~g} \mathrm{ha}^{-1}\right)$ and pendimethalin (1000 and $\left.750 \mathrm{~g} \mathrm{ha}^{-1}\right)$ caused the highest levels of injuries, ranging from 20 to $26 \%$ of phytointoxication.

Regarding the plant stand, treatments with pendimethalin $\left(500 \mathrm{~g} \mathrm{ha}^{-1}\right)$, [atrazine + S-metolachlor $]\left([601+471.2] \mathrm{g} \mathrm{ha}^{-1}\right)$, flumioxazin (25 $\mathrm{g} \mathrm{ha}^{-1}$ ) and control without herbicide, presented a fewer plants in relation to the other treatments.

Treatments with amicarbazone and pendimethalin affected the height of plants, however, even with shorter plants, the culms of these treatments did not show any reduction in the production of biomass (BMP). No herbicides affected BMP or the percentage of dry matter (DMP) at harvest. Some herbicides also caused reductions in Brix, but treatments with atrazine (2000 and $\left.1000 \mathrm{~g} \mathrm{ha}^{-1}\right)$, amicarbazone (210 g $\left.\mathrm{ha}^{-1}\right)$, trifluralin $\left(500 \mathrm{~g} \mathrm{ha}^{-1}\right)$ and flumioxazin (25 $\mathrm{g} \mathrm{ha}^{-1}$ ) showed no effect on this variable, which 
Table 3. Phytointoxication percentages (visual assessment 0 to 100\%), stand, height, green matterweight of the aerial part(BMP), percentage of dry matter of the aerial part(PS) and BRIX of sweet sorghum plants (28 DAE), after the application of the herbicides in preemergence in soil of sandy clay loam soil (field).

\begin{tabular}{lcccccc}
\hline \multicolumn{1}{c}{ Treatments $\left(\mathrm{g} \mathrm{ha}^{-1}\right)$} & $\begin{array}{c}\text { Phytointoxication } \\
(\%)\end{array}$ & $\begin{array}{c}\text { Stand } \\
(\text { plants } \\
\left.5 \mathrm{~m}^{-1}\right)\end{array}$ & $\begin{array}{c}\text { Height } \\
(\mathrm{cm})\end{array}$ & $\begin{array}{c}\text { BMP } \\
\left(\mathrm{g} 2 \mathrm{~m}^{-1}\right)\end{array}$ & $\begin{array}{c}\text { PS }(\%) \\
\left({ }^{\circ} \mathrm{Bx}\right)\end{array}$ \\
\hline atrazine (2000) & $2.50 \mathrm{~d}$ & $29.80 \mathrm{a}$ & $194.55 \mathrm{a}$ & $3101.67 \mathrm{a}$ & $15.53 \mathrm{a}$ & $7.68 \mathrm{a}$ \\
atrazine (1500) & $1.67 \mathrm{~d}$ & $29.83 \mathrm{a}$ & $186.82 \mathrm{a}$ & $2983.33 \mathrm{a}$ & $16.12 \mathrm{a}$ & $7.15 \mathrm{~b}$ \\
atrazine (1000) & $1.67 \mathrm{~d}$ & $30.08 \mathrm{a}$ & $187.22 \mathrm{a}$ & $3149.17 \mathrm{a}$ & $16.30 \mathrm{a}$ & $8.03 \mathrm{a}$ \\
amicarbazone (280) & $26.83 \mathrm{a}$ & $30.17 \mathrm{a}$ & $179.77 \mathrm{~b}$ & $3035.83 \mathrm{a}$ & $14.65 \mathrm{a}$ & $7.20 \mathrm{~b}$ \\
amicarbazone (210) & $20.00 \mathrm{~b}$ & $33.25 \mathrm{a}$ & $182.17 \mathrm{~b}$ & $2710.83 \mathrm{a}$ & $15.35 \mathrm{a}$ & $8.23 \mathrm{a}$ \\
S-metolachlor (480) & $12.00 \mathrm{c}$ & $34.08 \mathrm{a}$ & $190.20 \mathrm{a}$ & $3469.17 \mathrm{a}$ & $18.41 \mathrm{a}$ & $7.07 \mathrm{~b}$ \\
trifluralin (500) & $14.17 \mathrm{~b}$ & $34.33 \mathrm{a}$ & $189.08 \mathrm{a}$ & $1890.83 \mathrm{a}$ & $15.28 \mathrm{a}$ & $7.64 \mathrm{a}$ \\
pendimethalin (1000) & $26.17 \mathrm{a}$ & $35.17 \mathrm{a}$ & $173.12 \mathrm{~b}$ & $1866.67 \mathrm{a}$ & $15.91 \mathrm{a}$ & $7.06 \mathrm{~b}$ \\
pendimethalin (750) & $22.50 \mathrm{a}$ & $39.00 \mathrm{a}$ & $181.57 \mathrm{~b}$ & $1848.33^{\mathrm{a}}$ & $15.60 \mathrm{a}$ & $6.73 \mathrm{~b}$ \\
pendimethalin (500) & $17.00 \mathrm{~b}$ & $20.25 \mathrm{~b}$ & $176.43 \mathrm{~b}$ & $2596.67 \mathrm{a}$ & $15.39 \mathrm{a}$ & $7.35 \mathrm{~b}$ \\
[atrazine+S-metolachlor] ([601+471.2]) & $8.33 \mathrm{c}$ & $24.08 \mathrm{~b}$ & $185.05 \mathrm{a}$ & $3039.17 \mathrm{a}$ & $17.31 \mathrm{a}$ & $7.42 \mathrm{~b}$ \\
flumioxazin (25) & $6.17 \mathrm{c}$ & $24.33 \mathrm{~b}$ & $189.85 \mathrm{a}$ & $2620.00 \mathrm{a}$ & $15.88 \mathrm{a}$ & $7.76 \mathrm{a}$ \\
Control & $0.00 \mathrm{~d}$ & $26.92 \mathrm{~b}$ & $189.75 \mathrm{a}$ & $2789.17 \mathrm{a}$ & $16.29 \mathrm{a}$ & $8.27 \mathrm{a}$ \\
\hline F & $12.18 * *$ & $2.31 * *$ & $2.15 * *$ & $1.32^{\text {ns }}$ & $0.99^{\text {ns }}$ & $2.05^{* *}$ \\
CV (\%) & 55.41 & 27.94 & 5.53 & 41.80 & 14.84 & 10.85 \\
\hline
\end{tabular}

** Means in the same column followed by the same letter do not differ, at $5 \%$ probability by the Scott-Knott test. ns - not significant.

is important for assessing the quality of sweet sorghum biomass for the industry. However, for ethanol production from sweet sorghum to be economically viable, Brix values between 14.25 to 14.50 are needed (May et al., 2013).

Considering only biomass (BMP), all herbicides applied in preemergence in the sandy clay loam soil were selective for sweet sorghum. In this case, it is possible that some herbicides may show a small reduction in Brix (maximum $1.5^{\circ} \mathrm{Bx}$ ), which may also represent lower quality of biomass for industry. If we consider the effects on BMP and Brix together, the selective treatments for this type of soil and for this cultivar are atrazine (2000 and $1000 \mathrm{~g}$ $\mathrm{ha}^{-1}$ ), amicarbazone (210 $\left.\mathrm{g} \mathrm{ha}^{-1}\right)$, trifluralin (500 $\left.\mathrm{g} \mathrm{ha}^{-1}\right)$ and flumioxazin $\left(25 \mathrm{~g} \mathrm{ha}^{-1}\right)$. 


\section{Clay soil:}

As well as the results presented in the sandy clay loam soil, all treatments have phytointoxication levels $\leq 25 \%$, and only treatments with atrazine (1500 and $1000 \mathrm{~g} \mathrm{ha}^{-1}$ ), amicarbazone (140 $\mathrm{g} \mathrm{ha}^{-}$ $\left.{ }^{1}\right)$ and flumioxazin $\left(25 \mathrm{~g} \mathrm{ha}^{-1}\right)$ did not differ from the control (Table 4). Similar results were also observed in clay texture soil with other sweet sorghum cultivars, showing phytointoxication levels below $10 \%$ with the application of atrazine (1500 $\left.\mathrm{g} \mathrm{ha}^{-1}\right)$ and flumioxazin (50 $\left.\mathrm{g} \mathrm{ha}^{-1}\right)$ in preemergence (Galon et al., 2016).

Considering only the final stand, treatments with trifluralin, pendimethalin (1000 and $750 \mathrm{~g}$ $\left.\mathrm{ha}^{-1}\right)$, [atrazine + S-metolachlor] and imazethapyr (84.8 $\left.\mathrm{g} \mathrm{ha}^{-1}\right)$ demonstrated possible interferences in the formation of the stand, presenting fewer emerged plants. The applications of the formulated mixture of [atrazine + S-metolachlor] ([1665 + 1035] $\mathrm{g} \mathrm{ha}^{-1}$ ) and S-metolachlor (1440 $\mathrm{g} \mathrm{ha}^{-1}$ ) in preemergence of sweet sorghum cultivars showed a decreased plant stand at $35 \mathrm{DAE}$, with minimum values of $30 \%$ among the studied cultivars (Galon et al., 2016).

Silva et al. (1999) observed that the sorghum cultivar AG 1016, sown 150 days after the application of imazethapyr (200 $\mathrm{g} \mathrm{ha}^{-}$ $\left.{ }^{1}\right)$ in the soybean crop, showed symptoms of phytointoxication between 12 and 20\%, with a negative effect on plant height and panicle length, although it did not interfere with the final stand and grain yield.

In a study with the objective of evaluating the residual activity of herbicides used in soybeans, as well as their effects on the sorghum crop in succession, low levels of phytointoxication were observed with the use of flumioxazin and high sensitivity of the sorghum crop to the sulfentrazone herbicides diclosulam and imazethapyr (Dan et al., 2010).

Since no herbicide affected the quality of harvested biomass (assessed using Brix), the main evaluated variable that correlates with productivity is BMP. In this case, of the 16 treatments evaluated in this type of soil, nine did not affect this variable and can be considered selective for sweet sorghum: atrazine (2000, 1500 and $1000 \mathrm{~g} \mathrm{ha}^{-1}$ ), amicarbazone (280 $\mathrm{g}$ $\mathrm{ha}^{-1}$ ), S-metolachlor (480 $\left.\mathrm{g} \mathrm{ha}^{-1}\right)$, pendimethalin $\left(500 \mathrm{~g} \mathrm{ha}^{-1}\right)$, [atrazine + S-metolachlor $]([601+$ 471.1] $\mathrm{g} \mathrm{ha}^{-1}$ ) and imazethapyr (63.6 and 42.4 $\left.\mathrm{g} \mathrm{ha}^{-1}\right)$.

Generally, organic matter and clay minerals are the main factors in the retention of herbicides applied to the soil (Li et al., 2003). In other words, the difference in soil textures can provide greater or lesser adsorption of the herbicides to their colloids, making them less available for absorption by the plants, directly affecting the selectivity of the herbicides. In general, herbicides applied to sandy clay loam soil showed higher levels of phytointoxication and greater effects on the yield characteristics evaluated in relation to those applied to clay soils. In addition, the treatments applied in the greenhouse showed higher levels of phytointoxication in sweet sorghum plants when compared to experiments conducted in 


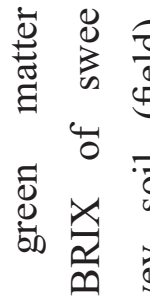

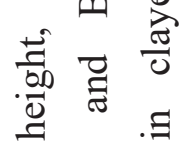

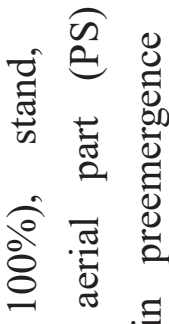

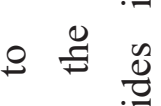

$\circ \stackrel{4}{0} \cdot \frac{\overline{0}}{\overline{0}}$

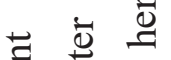

离 䒿

总

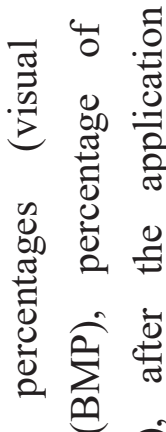

.

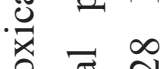

葛

冚

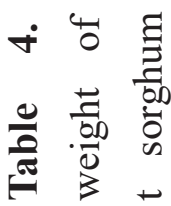

\begin{tabular}{llllllllllll}
\hline & 0 & 0 & 0 & 0 & 4 & 4 & 1 & 0 & 0 & 8 & 4
\end{tabular}

ㅇำ

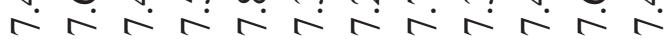

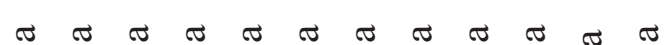

尺

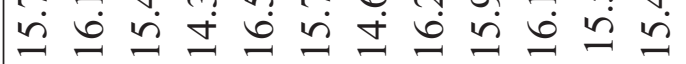

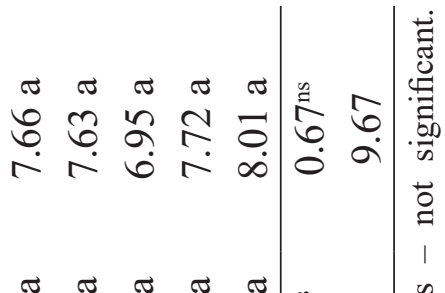

क

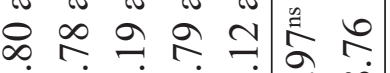

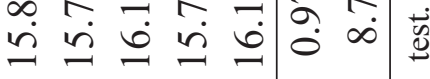

(1.

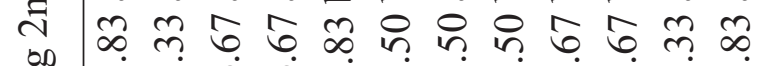

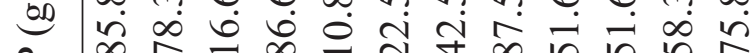

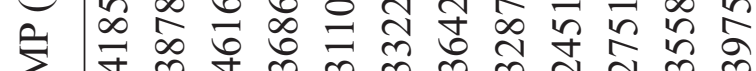

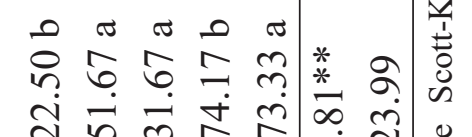

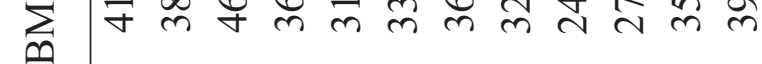

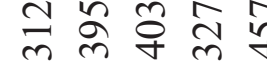

ह્ટ

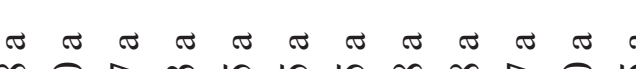

$\infty$ กิ

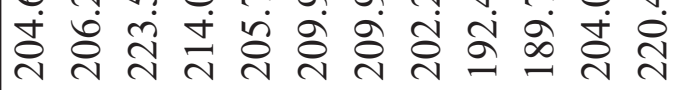

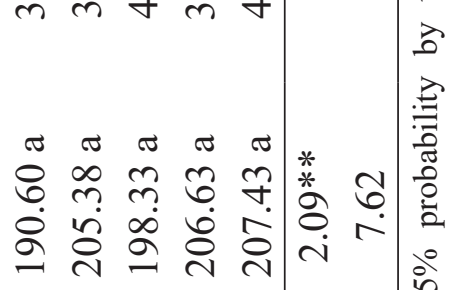

工

(1)

$\stackrel{n}{\stackrel{0}{\Xi}}$

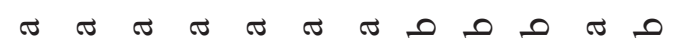

$m \infty$ 두

m n $\infty$

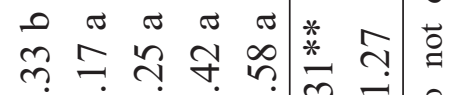

๙ें

营

.0

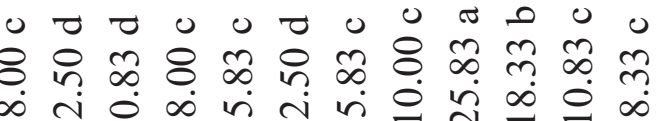

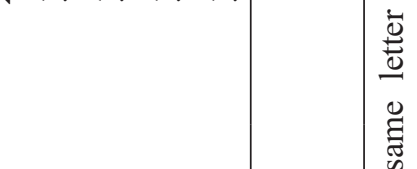

훌

尝 
the field, for the same soil textures.

\section{Conclusions}

Treatments applied to sandy clay loam soil with atrazine (1000 and $\left.2000 \mathrm{~g} \mathrm{ha}^{-1}\right)$, amicarbazone (210 $\left.\mathrm{g} \mathrm{ha}^{-1}\right)$, trifluralin (500 $\left.\mathrm{g} \mathrm{ha}^{-1}\right)$ and flumioxazin $\left(25 \mathrm{~g} \mathrm{ha}^{-1}\right)$ provided the lowest levels of phytointoxication and the best results of the evaluated yield components (BMP and Brix) were observed, indicating greater selectivity for this type of soil.

In relation to clay soil, treatments with atrazine (1000, 1500 and $2000 \mathrm{~g} \mathrm{ha}^{-1}$ ), amicarbazone (280 $\mathrm{g} \mathrm{ha}^{-1}$ ), S-metolachlor (480 g $\left.\mathrm{ha}^{-1}\right)$, [atrazine + S-metolachlor $]([601+471.2] \mathrm{g}$ $\left.\mathrm{ha}^{-1}\right)$, pendimethalin $\left(500 \mathrm{~g} \mathrm{ha}^{-1}\right)$ and imazethapyr (42.4 and $63.6 \mathrm{~g} \mathrm{ha}^{-1}$ ) provided the lowest levels of phytointoxication and improved results for the variables BMP and Brix were observed, indicating greater selectivity of herbicides for this type of soil.

The treatments applied to sandy clay loam texture soil showed higher levels of phytointoxication to sweet sorghum, in relation to those applied to soil with clay texture.

\section{Acknowledgements}

This study was financed in part by the Coordenação de Aperfeiçoamento de Pessoal de Nível Superior - Brasil (CAPES) - Finance Code 001.

\section{References}

ACOMPANHAMENTO DA SAFRA BRASILEIRA [DE] GRÃOS: safra 2018/19. Brasília, DF: Conab, v. 6, n. 7, jul. 2019. Disponível em: $<$ https://www.conab.gov.br/infoagro/safras/graos>. Acesso em: 31 out. 2019.

ALBUQUERQUE, C. J. B.; TARDIN, F. D.; PARRELA, R. F. C.; GUIMARÃES, A. S.; OLIVEIRA, R. M.; SILVA, K. M. J. Sorgo sacarino em diferentes arranjos de plantas e localidades de Minas Gerais, Brasil. Revista Brasileira de Milho e Sorgo, v.11, n.1, p.6985, 2012. DOI: 10.18512/1980-6477/rbms. v11n1p69-85.

APPIAH-NKANSAH, N. B.; LI, J.; ROONEY, W.; WANG, D. A review of sweet sorghum as a viable renewable bioenergy crop and its techno-economic analysis. Renewable Energy, v.143, p.1121-1132, 2019. DOI: 10.1016/j. renene.2019.05.066.

BRASIL. Ministério da Agricultura, Pecuária e Abastecimento. AGROFIT: sistema de agrotóxicos fitossanitários. Brasília, DF, c2003. Disponível em: <http://agrofit.agricultura.gov. br/agrofit_cons/principal_agrofit_cons $>$. Acesso em: 1 nov. 2019.

CORREIA, N.M.; GOMES, L.J.P. Selectivity of saflufenacil for sweet sorghum and potential use of Na-bentazon as a safener. Planta Daninha, 
v.33, n.2, p.267-274, 2015. DOI: 10.1590/010083582015000200012 .

DAN, H.A.; DAN, L.G.M.; BARROSO, A.L.L.; PROCÓPIO, S.O.; OLIVEIRA JR, R.S.; SILVA, A.G.; LIMA, M.D.B.; FELDKIRCHER, C. Residual activity of herbicides used in soybean agriculture on grain sorghum crop succession, Planta Daninha, v.28, p.1087-1095, 2010. DOI: $10.1590 / \mathrm{S} 0100-83582010000500016$.

DURÃES, F. O. M.; MAY, A.; PARRELA, R. A. C.; SCHAFFERT, R. E.; GARCIA, J. C. Sistema agroindustrial do sorgo sacarino no Brasil e a participação público - privada: oportunidades, perspectivas e desafios. Embrapa Milho e Sorgo, 2012. Documentos 138.

GALON, L.; FERNANDES, F. F.; ANDRES, A.; SILVA, A. F.; FORTE, C. T. Selectivity and efficiency of herbicides in weed control on sweet sorghum. Pesquisa Agropecuária Tropical, v.46, n.2, p.123-131, 2016. DOI: 10.1590/198340632016v4639431.

KARAM, D.; CARNEIRO, A. A.; CRUZ, M. B.; COSTA, G. T.; MAGALHÃES, P. C. Seletividade de Clomazone a cultura do milho obtida através do uso do Permit. In: CONGRESSO NACIONAL DE MILHO E SORGO, 24., 2002, Florianópolis, SC. Meio ambiente e a nova agenda para o agronegócio de milho e sorgo: [resumos expandidos]. Sete Lagoas: ABMS: Embrapa Milho e Sorgo; Florianópolis: Epagri, 2002.
Disponível em: <https://ainfo.cnptia.embrapa. $\mathrm{br} /$ digital/bitstream/item/34900/1/Seletividadeclomazone.pdf>. Acesso em: 1 nov. 2019.

LI, H.; SHENG, G.; TEPPEN, B. J.; JOHNSTON, C. T.; BOYD, S. A. Sorption and desorption of pesticides by clay minerals and humic acid-clay complexes. Soil Science Society of America Journal, v.67, n.1, p.122-131, 2003. DOI: $10.2136 /$ sssaj2003.1220a. DOI: 10.2136/ sssaj2003.1220a.

MACHADO, F. G.; JAKELAITIS, A.; GHENO, E. A.; OLVEIRA JR., R. S.; RIOS, F. A.; FRANCHINI, L. H. M.; LIMA, M. S. Performance de herbicidas para o controle de plantas daninhas no sorgo. Revista Brasileira de Herbicidas, v.15, n.3, p.281-289, 2016. DOI: 10.7824/rbh.v15i3.476.

MACIEL, C. D. G.; OLIVEIRA NETO, A. M.; GUERRA, N.; LEAL, G. B.; SILVA, A. A. P.; SOARES, C. R. B.; KARPINSKI, R. A. K. Selectivity of herbicide associations with chemical protector in the treatment of sweet sorghum hybrid seeds. Planta Daninha; v.35:e17167026, 2017. DOI: 10.1590/s010083582017350100021 .

MARTINS, A. M.; PARRELA, R. A. da C.; LOPES, D. de C.; SCHAFFERT, R. E.; PARRELA, N. N. L. D.; NEVES, W. dos S.; SILVA, A. P. C. M. Período e utilização industrial de cultivares de sorgo sacarino visando a produção 
de etanol. Revista Brasileira de Milho e Sorgo, Sete Lagoas, v. 16, n. 2, p. 217-231, 2017. DOI: 10.18512/1980-6477/rbms.v16n2p217-231.

MAY, A.; MENDES, S.M.; SILVA, D.D.; PARRELLA, R.A.C.; MIRANDA, R.A.; SILVA, A.F.; PACHECO, T.T.; AQUINO, L.A.; COTA, L.V.; COSTA, R.V.; KARAM, D.; PARRELLA, N.N.L.D.; SCHAFFERT, R.E. Cultivo de Sorgo Sacarino em Áreas de Reforma de Canaviais. Desempenho Produtivo de Sorgo Sacarino Cultivado em Reforma de Canaviais nos Últimos Anos. Circular Técnica, n.186, 2013.

RIBAS, P.M. Origem e importância econômica. In: BORÉM,A.; PIMENTEL, L.D.; PARRELLA, R.A.C. Sorgo: do plantio à colheita. Viçosa: Ed. Universidade Federal de Viçosa, 2014. p.9-36.

SANTOS, H. G. dos; JACOMINE, P. K. T.; ANJOS, L. H. C. dos; OLIVEIRA, V. A. de; LUMBRERAS, J. F.; COELHO, M. R.; ALMEIDA, J. A. de; CUNHA, T. J. F.; OLIVEIRA, J. B. de. Sistema brasileiro de classificação de solos. 3. ed. rev. e ampl. Brasília, DF: Embrapa, 2013. 353 p.

SILVA, A. A.; OLIVEIRA JR., R. S.; COSTA, E. R.; FERREIRA, L. R. Efeito residual no solo dos herbicidas imazamox e imazethapyr para as culturas de milho e sorgo. Planta Daninha, v.17, n.3, p.345-354, 1999. DOI: 10.1590/S010083581999000300003.
SILVA, C.; SILVA, A. F.; VALE, W. G.; GALON, L.; PETTER, F. A.; MAY, A. KARAM, D. Interferência de plantas daninhas na cultura do sorgo sacarino. Bragantia, v.73, n.4, p.1-8, 2014. DOI: $10.1590 / 1678-4499.0119$.

SILVA, M. M.; SANTOS, J. B.; FERREIRA, E. A.; BRITO, O. G.; DONATO, L. M. S. Plantas forrageiras e daninhas sensíveis a resíduos atmosféricos de clomazone. Planta Daninha, v35:e017165078, 2017. DOI: 10.1590/s010083582017350100059 .

SOLANO, C.S.; PONCIANO, N.J.; DAHER, R.F.; PARRELA, R.A. da C.; SOUZA, P.M.; ROCHA, J.P.S.M. Qualidade do caldo para produção de etanol em cultivares de sorgo sacarino sob adubação nitrogenada. Revista Brasileira de Sorgo e Milho, v.16, n.3, p.388400, 2017. DOI: 10.18512/1980-6477/rbms.

v16n3p388-400. 